\title{
Exploration on the Model of Entrepreneurial Education
}

\author{
Zhao Gengsheng ${ }^{*}$, Xiang Peijun, Fu Zhibing, Li Sen \\ University of Shanghai for Science and Technology, Experimental Teaching Demonstration Center of \\ Economics and Management, Shanghai 200093
}

Keywords: Innovation and Entrepreneurship; Entrepreneurship Education; Education Model

\begin{abstract}
The cultivation of college students' innovative and entrepreneurial ability is the core measure of China's higher education oriented to society and market economy. As a bridge connecting the society, colleges and universities need a perfect entrepreneurial education concept and entrepreneurship education system. China's innovation and entrepreneurship education started late than those in Europe and the United States, and the concepts and models of innovation and entrepreneurship education are backward and single. This paper analyzes the characteristics of innovation and entrepreneurship education mode at home and abroad, combines the characteristics of innovation and entrepreneurship education in China's colleges and universities under the new situation, draws on new measures and achievements of entrepreneurship reform in domestic universities, and puts forward some suggestions on constructing innovative entrepreneurship education mode.
\end{abstract}

\section{高校创业教育模式的探索}

$$
\text { 赵庚升 } \text {, 项培军, 付直兵, 李森 }
$$

上海理工大学国家级经济管理实验中心，上海 200093

关键词：创新创业，创业教育，教育模式

摘 要: 大学生创新创业能力的培养是我国高等教育面向社会与市场经济的核心举措。高校作 为衔接社会的桥梁, 更需要完善的创业教育理念与创业教育体系。我国的创新创业教育较欧 美等国家起步晚, 创新创业教育理念与模式存在落后、单一等问题。本文通过分析国内外创 新创业教育模式特色, 结合新形势下我国高校创新创业教育的特点, 吸取国内高校创业改革 的新举措与成果, 提出了若干条关于构建创新创业教育模式的建议。 中图分类号: G712 文献标识码：A

\section{1. 引 $\square$ 言}

创新创业教育既是高等教育改革发展的必然趋势，同时也是经济社会发展对其提出的必然 要求。1998 年，首届世界高等教育大会通过的《21 世纪的高等教育: 展望与行动世界宣言》 中强调指出：高等教育要把学生创业技能的培养作为关注的主要问题。同时一起通过的《高 等教育改革和发展的优先行动框架》也强调要把学生创业精神、创业能力的培育作为学校教 育的中心目的, 通过创新创业教育要使学生能够成为工作岗位的积极创造者, 求职者与企业 双方之间都是主体，工作岗位只是载体，国际组织明确了创新创业教育在高等教育中起到的 重要作用。

创新创业教育是我国当今高等教育的主题，是社会发展的推动力。2010 年，教育部颁布《关 于大力推进高等学校创新创业教育和大学生自主创业工作的意见》, 文件中明确要求我国高等 学校大力开展创新创业教育, 不断探索新途径和新方法, 不同的模式有着不同的特点, 对创 新创业教育起着不同程度的作用。我国高校创新创业教育起步较晚, 发展总体水平有限, 模 式比较匮乏, 与建设创新型国家的战略不相符。基于此, 应该借鉴国内外成熟优秀的模式, 
精炼取精, 结合我国的国情, 寻找出合适的模式以促进我国创新创业教育的发展。

\section{2. 国外创新创业教育的模式与发展}

\section{1 国外创新创业教育的发展理念}

理念作为行动的指南, 来源于行动又高于行动。十九世纪初国外就开展创新创业教育, 国 外成熟的创新创业教育理念在实践中不断完善并对创新创业教育实践提供战略性和前瞻性指 导。美国于 1919 年开设了创业类教育课程。哈佛商学院于 1947 年正式开设创业课程《新创 业管理》。十九世纪 50 年代, 德国在职业院校中创建了 “模拟公司”, 这是是当时创业教育中 最早，同时，也是最具影响力的创业实践教育。1966 年，印度提出了 “自我就业教育”理念， 鼓励毕业生积极创业。日本于 1994 年开设了“综合学科”，把《产业社会与人》列为创业必修 课程。

\section{2 国外创新创业教育的理念}

澳大利亚尤为重视国内小企业创业教育, 澳大利亚技术与继续教育学院就如何创立小企业 的创业教育作为一种全新的教育理念, 这是有别于传统就业教育的另一种开放式的创新教 育, 旨在培养全能型的创业人才。美国的创业教育旨在培养多元化人才, 提出创业教育有别 于就业教育, 要全面考虑每名学生的自由发展。日本提出培养大学生的创业精神与创业教育 理念, 通过创业教育, 培养学生创业意识和创业精神, 提高创业技能, 使学生能够很好地面 对社会现实的挑战, 并具有冒险精神。英国将创业作为一种未来的职业选择, 认为学生接受 创业教育不仅仅是创建一个企业, 更重要的在于培养学生的创业精神, 适应知识经济时代的 挑战。法国把创业教育和增强国家竞争力相联系。韩国将大学生创业教育与提高国民素质联 系在一起。新加坡则确立了创业教育要适合经济和工业发展的指导思想, 其创业教育起步虽 然较晚，但由于高校、企业单位和国家之间的联动合作，实现了跨越式发展。 ${ }^{[1]}$

\section{3 国外创新创业教育模式及特点}

国外创新创业教育模式根据不同学校确立培养目标, 具有针对性与多样性的特点。经过多 年实践，国外高等院校创新创业教育模式已经自成一套系统，取得了良好的发展效果。

美国是高校创业教育的先驱者, 它的创业教育模式主要分为两类: 一类是聚焦式创业教 育。哈佛大学商学院是聚焦式创业教育的典型, 创业课程仅开设在商学院与管理学院, 课程 内容系统化和专业化, 通过课程与活动培养学生的创业热情与认同感、使命感。另一类是面 向全校学生开设创业课程的普适性创业教育 (磁石式、辐射式与混合式)。麻省理工学院和杜 克大学是磁石式的典型代表, 面向全体学生在商学院等特定院系开设创业课程。康奈尔大学 是辐射式的典型代表, 面向本院系学生开设创业课程, 旨在强调教师参与的创新创业教育过 程。斯坦福大学是混合式的典型代表, 这种模式兼并了如上两种模式的特性。国外典型创新 创业教育实践模式主要有百森商学院的“强化意识”模式、哈佛大学的 “注重经验”模式与斯坦 福大学的“产学研一体化”创新创业教育模式。

\section{3. 我国创新创业教育模式}

近些年, 我国高校创新创业教育逐渐受到政府、高校与社会的重视。2002 年教育部公布了 9 所试点院校; 2012 年教育部设立了国家级大学生创新创业训练计划项目, 28 所部属院校和 30 个省 (直辖市、自治区) 的地方院校列入项目试点名单。目前, 我国创新创业教育模式 ${ }^{[3-5]}$ 主要有以下 5 种:

（1）大学生竞赛项目导向模式。竞赛由政府部门、协会部门和企业等主办，学生自由组 队, 在教师的指导下进行一系列有序的活动（选题、调研、撰写创业计划书、项目汇报、成 果展示等)。在整个过程中, 学生通过团队协作方式, 共同完成整个项目。通过项目的全过程 
加深学生对理论的理解, 提升学生对知识运用, 促进团队合作和科研实践的能力, 达到能力 和素质的多方面培养。

(2) 教师教研导向模式。该模式吸收优秀学生参与相关教师的教研活动。通过参与到相 关教研活动, 优秀学生能够提前接触教研创新活动, 有助于培养其创新思维, 尽早发掘潜力。

（3）自主创业模式。自主创业模式是指大学生在学校或政府提供的政策、资金、环境和 平台等的基础上，依靠自身要素实现创办产业、解决就业问题的教学改革模式和人才培养模 式, 这也是教育部大力提倡的创业模式。大学生自主创业一般是在校内外就业导师的指导下, 进行市场调查、财务分析, 撰写创业计划书, 实施创业计划, 进行具体的日常管理工作。大 学生自主创业可减轻社会就业压力, 使其将所学知识技能学以致用, 并能更加适应激烈的就 业竞争。

（4）课堂拓展模式。强调创新创业教育不仅体现在课堂教学上, 更重要的是将其拓展到 课外活动中, 通过课外拓展活动提升大学生创新创业能力。课堂拓展实质是为提高大学生创 新创业能力而进行的准备。

（5）大学生导师全程模式。大学生导师制是培养适合社会发展的大学生的有效途径。大 学生导师制有利于学生构建合理的知识结构, 有利于引导学生适应大学的学习和生活, 有利 于培养学生的自学能力和创新能力, 有利于因材施教, 有利于教师队伍的自我优化。大学生 导师在培养大学生创新创业能力的过程中扮演专业导师和科研导师的角色, 引导提升学生的 创新创业意识和能力。该模式不是独立的创新创业人才培养模式, 而常常贯穿于其它模式之 中，在以上模式中均可以发挥作用。

在实践中, 我国创新创业教育模式以学生竞赛项目导向模式、教师科研导向模式、自主创 业模式、课堂拓展模式为主, 大学生导师全程模式等并未在全国范围内流行开来。目前, 在 我国各大高校广泛开展的另外一种模式: 商学院模式, 而商学院模式存在过于聚焦企业管理、 让商业计划成为了创业的代名词, 并将之置于核心位置, 削弱了非商业环境下创业的潜能, 创业环境过多地集中在市场模式, 教学设计集中在创业行为培养, 忽略了创业技能态度的培 养等问题。

\section{4. 国内高校创新创业教育模式的探索}

上海理工大学作为上海市首批试点创业教育的改革院校, 在创新创业教育中学校坚持创业 教育的知识创新取向, 积极探索创新创业教育的有效载体和抓手, 在实践中形成以创新创业 为核心的五芒星体系 (课堂教学、大学生竞赛、创业班、创业学院和企业孵化基地), 这套体 系经历了多年的实践与尝试, 成效明显。学校注重提升学生的终身学习和可持续发展的素质, 除课堂教学模式创新外, 更加注重实践教学环节的实效性, 有针对性地培养学生开拓进取、 坚忍不拔的内在品质，团队协作、改革创新的思维方式和行为习惯及团队执行力等素质。

课堂教学方面, 注重培养学生创新创业的精神, 致力于实现全校 3\% 7\%的学生成功创业。 在这一教学目标的引导下, 自 2010 年起, 上海理工大学面向全校所有专业开设了创新教育课 程, 比如《创业管理实训》、《机械创新设计与实践》、《大学生领导力实训》等系列课程, 并 分三年重点建设 30 门核心课程, 培养大学生的创业精神和创业能力。并且设立“通识-创新创 业类”板块, 要求所有学生必须获得 4 学分的创新创业学分, 该学分的获取并不一定是通过课 程获得, 更注重以理论应用、创新实践及成果来培养并认定创新创业能力。论文、创业项目、 授权专利、创新作品、竞赛获奖、技能、创业成果等创新创业实践活动均纳入学分认定范围。

创新创业大赛方面, 上海理工大学自开展创新创业教育以来, 成功举办各种创新创业大 赛, 并不断改进大赛质量。2016 年由教务处、校友工作联络处联合举办了“上理创客共赢未 来”大学生创业大赛, 大赛突出强调实践效应, 将项目落地、运营业绩、团队执行力、投融资、 导师参与度等纳入大赛评比成绩, 充分发挥上理创客联盟校友导师的资源和创业经验, 形成 了“校友创客导师”+“导师跨界组合”+“无私奉献”的上理工创业教育独特模式, 大大增强了学 生创业的成功率。参与决赛的 20 支队伍, 其中注册成立公司的 14 家、实现盈利的 10 家、获 
得融投资 4 家、获得各种大赛奖励 4 家。

创业班方面, 上海理工大学率先探索创业专业教育, 于 2009 年开设了国内首个“创业班” 及创业管理第二专业，为有志于并有能力创业的开拓实现梦想的平台。首期“创业班”共有 26 名学生, 有 20 名毕业生成功创业, 3 个项目获得了政府的创业基金支持, 2 个项目获 2011 年 新创业达人总决赛全国百强。

创业学院方面, 2015 年, 上海理工大学与北京中科创大创业教育投资管理有限公司宣布共 建“上海理工大学中科创大创业学院。双方将充分发挥在教学、资金、科技、平台、产业等方 面的优势, 以上海理工大学优势学科、特色专业为基础, 设立创新创业投资基金, 打造创新 创业实践基地, 共建二级实体创业学院, 探索“产、学、研、用、创”贯通的人才培养新模式。 据介绍, 该创业学院将充分整合上海理工大学各优势学科的教育资源和创新创业教育的成功 经验, 同时广泛借鉴国外高校创新创业教育的先进理念，积极实施在管理体制、培养模式、 课程体系等方面的创新探索, 将该学院建设成为学校打造创新创业教育升级版的“重要承载 区”。创新创业教育是学校的一张重要的办学名片, 此次学校引入社会资源, 夯实孵化平台, 助推成果转化, 探索 “产、学、研、用、创”贯通的人才培养新模式, 对学校进一步提升创新 创业教育水平具有重要意义。同时, 上海理工大学还宣布成立了 “尚理创客联盟”。互联网教 育领导品牌“沪江”创始人伏彩瑞当选联盟首届理事会主席, 21 位联盟理事均受聘成为学校第 三期创业班创业导师。

企业孵化基地方面, 上海理工大学、杨浦区人民政府和上海市科学技术协会联合组建了国 家大学科技园。科技园在运营发展中形成了以技术转移、创业孵化、研发服务特色, 具备了 专业、人才、政策等多方面的综合优势。科技园秉持 “先进制造业科技引擎”的总体定位, 着 力引进先进制造业领域的研发机构、检测中心、工程技术中心、产品设计中心等公共技术平 台、企业总部、培训机构等。科技园组建大学生创业孵化中心，依托天使基金为大学生创业 企业提供从创业辅导、工商注册、运营指导、金融服务等全方位的服务。同时为大学生创业 提供实习机会, 以个性化、创新性实验活动, 将知识创新与科技创业人才的培养融为一体。 2016 年 10 月, 一上海理工大学创新创业孵化基地一“尚理四和苑”揭牌, 这是上海理工大学企 业孵化方面的又一重大成果。

经过多年的发展, 上海理工大学在创新创业教育方面取得了杰出的成果, 形成了自己独特 的教育模式并不断推成创新以适应社会经济不断发展变化和新时期国家对高校创新创业发展 改革的新要求。上海理工大学创新创业教育走在各大高校创新创业教育前列, 实践中形成了 “课堂教学一创新创业大赛—创业班一创业学院一企业孵化基地”这一完整的系统化的教育模 式。

\section{5. 创新创业教育模式存在的问题与改善}

\section{1 当前创业教育存在的问题}

近年来, 我国高等教育取得了举世瞩目的成就, 但发展至今也碰到了诸多问题。对比国内 外创新创业教育 ${ }^{[6-7]}$, 当前存在的不足主要包含五大问题: 一、由教育理念滞后而导致地创新 创业意识不足; 二、高校课程体系不健全, 创新创业教育模式千篇一律, 缺乏适应自己学校 的创业体系; 三、教育考核机制单一，学分评价体系不完善; 四、创业教育与创新教育没有 有机的融合; 五、创新创业教育独立于专业教育。

\section{2 创新创业教育模式改善意见}

创新创业教育作为引领新时期我国经济发展的动力, 国家和政府大力支持创新创业教育在 全国各大高校展开，并对实践活动提供指导、政策扶持、资金援助等。在分析了众多创新创 业教育模式以及我国创新创业教育模式中存在的问题, 应该着手从以下方面改进我国创新创 业教育模式。 


\subsection{1 课程设计体现多样性和复合性}

首先，创新创业教育呈现在课程设计上应该是多样性的和复合性的。创新创业教育培养的 是学生的综合素质, 包括创新创业精神、创新创业勇气、创新创业知识和技能以及财务、管 理、运营、法律等基础性的知识, 则体现在课堂上的理论教育应该具有多样性和复合性。

\subsection{2 创新和创业深度结合}

创新教育和创业教育相辅相成, 具有一致性和协同性。创新是属性, 创业是目的。没有目 标的一味创新在市场经济角度看来是毫无意义的, 而没有创新性的创业也不是正真的创业, 正真的创业是具有创新性的创业, 能够引领行业发展方向, 提升自身竞争力。创新与创业应 该深度结合, 紧密联系, 而不是相互割裂, 这样才能真正提升学生的综合素质, 增强学生为 经济社会发展做出贡献的能力。

\subsection{3 创业教育与专业教育结合}

创业教育应当根据各大高校的学科特色和优势进行层次化、差异化和专业化分工, 而不是 对所有学生采取同一种教育模式。依据各个学生的专业教育背景, 对学生进行具有专业性的 创业教育, 对如生物医药、化学、计算机、机械等具有创新性专业在提供基础通识性知识的 同时，更加强调专业性创新创业教育。

\subsection{4 加强创新创业教育跨校区、跨地区合作}

创新创业教育应该具有前瞻性和开阔性，而不应该只局限在本校区内部，否则创新创业教 育就变成狭险的教育。加强创新创业教育跨校区、跨地区合作，不仅能提高创新创业教育交 流合作，还能发挥各高校的优势学科特色和人才的合作培养。

\subsection{5 强化创新创业教育的实践}

目前, 我国各大高校创新创业实践性多数还停留在理论性阶段, 进入实际实践阶段的却比 较少。理论需要实践检验, 实践出真知, 实践才能产生真正的效益。我们可以采取创业班、 创业学院、创业实践基地和创新创业校企合作等方式为学生提供实践的平台和指导。相信, 经过实践，学生们对创新创业认识更加深刻、创新创业技能和精神也将大大提升。

\subsection{6 引入优秀创业导师, 以创客带创客}

目前, 我国各高校学术性导师对创业热情不高, 而且没有创业的经验和实践, 此时, 以学 术性导师指导的创新创业教育效果可能比较差。那么, 我们各大高校就应该考虑引入创业导 师对那些具有强烈创业意识的学生给予实战性的指导, 让他们能够见识到实际社会中的创新 创业的情形, 也能够增强学生的实战能力。引入优秀的创业校友或行业精英, 以创客带动学 生们的创新创业热情。

\section{参 考文 献}

[1]周文华．国外高校创新创业教育发展特点及启示[J]．新余学院学报，2015(03)：141-143

[2]田玉敏. 国外高校创新创业教育的理念、模式与路径[J]. 中国国情国力，2016(04)：64-66 [3]王万山, 汤明. 国内外高校创新创业教育模式比较研究[J]. 江学院学报( 社会科学版), 2012(02): 116

[4]余 永, 王志军. 高校创新创业教育模式研究[J]. 学术论坛, 2013(12)：232-235

[5]周刚, 陈洪伟. 普通高校大学生创新创业教育模式探索与实践[J]. 就业与创业, 2016(08): 109-110

[6]胡桃, 沈莉. 国外创新创业教育模式对我国高校的启示[J]. 中国大学教学, 2013(02): 91-93 
[7]江玮潘, 李文, 汪丽琴等. 我国创新创业教育发展存在的问题及对策[J]. 科技广场, 2013(11): $253-254$ 